\title{
Experimental Research on NO Removal for Fixed Bed Reactor and Fluidized Bed Reactor at Low Temperature
}

\author{
Yebin Yin, Bing Xia, Jinghong Lian, Guang Yang, Guoyou Xu, Xiang Gouª, \\ Enyu Wang, Liansheng Liu, Jinxiang Wu
}

School of Energy and Environmental Engineering, Hebei University of Technology, Tianjin 300401, China

${ }^{a}$ Corresponding author email: gouxiang@sina.com

Keywords: SCR; low temperature denitrification; fixed bed reactor; fluidized bed reactor

\begin{abstract}
The method of the selective catalytic reduction (SCR) has become one of the most effective applications of $\mathrm{NO}_{\mathrm{x}}$ removal technology. Most studies focus the side on fixed bed denitrification at low temperature low space velocity experimental condition, while few studies about denitrification at low temperature high space velocity experimental condition. The catalyst, $\mathrm{Mn}-\mathrm{Ce} / \mathrm{AC}$, has been prepared by impregnation method in this paper. Under the experimental condition of low temperature high space velocity, catalytic activity was researched in fixed bed denitrification reactor and fluidized bed denitrification reactor respectively. Results show that, the catalytic NO removal is $10.5 \%$ at $180^{\circ} \mathrm{C}$, the space velocity is $100000^{-1}$, in fixed bed denitrification reactor; while it is $81.3 \%$ in fluidized bed denitrification reactor.
\end{abstract}

\section{Introduction}

$\mathrm{NO}_{\mathrm{x}}$ is one of the most serious atmosphere pollutants, which pollution and damage our living environment more and more serious. The emission of $\mathrm{NO}_{\mathrm{x}}$ is increasing with the rapid development of our country electric power industry [1,2]. At present, the method of the selective catalytic reduction (SCR) is the main measures of $\mathrm{NO}_{\mathrm{x}}$ removal in coal-fired power plant [3]. Most research fellow concentrate the attention on fixed bed denitrification reactor in conventional, and the research and development of fluidized bed is due to its advantage in the combustion process [4-8]. In this paper, catalyst was put into fluidized bed denitrification reactor of low temperature high space velocity experimental condition, realized an ideal fluidization state by suitable the space velocity. As a result of the contact area was increased between catalyst and reaction gas, and the catalytic denitration efficiency was enhanced.

\section{SCR denitrification technology}

SCR method is defined as the $\mathrm{NO}_{\mathrm{x}}$ in the flue gas, which was transformed to $\mathrm{N}_{2}$ and $\mathrm{H}_{2} \mathrm{O}$ selectively by a series of chemical reactions after the catalyst was added into the reactor under a certain temperature condition. The reducing agent, $\mathrm{NH}_{3}$, is not directly reacted with the $\mathrm{O}_{2}$ unreacted in the flue gas. Therefore, this method is known as "selective". There are other reducing agents as well as $\mathrm{H}_{2}, \mathrm{CO}, \mathrm{CH}_{4}$ and the like [9]. Table 1.shows that several common reducing agents SCR chemical equations.

Currently, the most widely used reducing agent is $\mathrm{NH}_{3}$. There are main reaction equations of $\mathrm{NH}_{3}$-SCR as follows [10]:

$$
\begin{aligned}
& 4 \mathrm{NO}+4 \mathrm{NH}_{3}+\mathrm{O}_{2}=4 \mathrm{~N}_{2}+6 \mathrm{H}_{2} \\
& 2 \mathrm{NO}+4 \mathrm{NH}_{3}+\mathrm{O}_{2}=3 \mathrm{~N}_{2}+6 \mathrm{H}_{2} \mathrm{O} \\
& 8 \mathrm{NH}_{3}+6 \mathrm{NO}_{2}=7 \mathrm{~N}_{2}+12 \mathrm{H}_{2} \mathrm{O}
\end{aligned}
$$




\begin{tabular}{ll} 
Reducing agent & \multicolumn{1}{c}{$\mathrm{SCR}$ chemical equation } \\
\hline $\mathrm{NH}_{3}$ & $4 \mathrm{NH}_{3}+4 \mathrm{NO}+\mathrm{O}_{2} \rightarrow 4 \mathrm{~N}_{2}+6 \mathrm{H}_{2} \mathrm{O}$ \\
$\mathrm{H}_{2}$ & $2 \mathrm{NO}+\mathrm{H}_{2}+\mathrm{O}_{2} \rightarrow \mathrm{N}_{2}+4 \mathrm{H}_{2} \mathrm{O}$ \\
$\mathrm{CO}$ & $4 \mathrm{CO}+\mathrm{O}_{2}+2 \mathrm{NO} \rightarrow \mathrm{N}_{2}+4 \mathrm{CO}_{2}$ \\
$\mathrm{CH}_{4}$ & $\mathrm{CH}_{4}+2 \mathrm{NO}+\mathrm{O}_{2} \rightarrow \mathrm{CO}_{2}+\mathrm{N}_{2}+2 \mathrm{H}_{2} \mathrm{O}$ \\
$\mathrm{C}_{2} \mathrm{H}_{5} \mathrm{OH}$ & $\mathrm{C}_{2} \mathrm{H}_{5} \mathrm{OH}+4 \mathrm{NO}+3 \mathrm{O}_{2} \rightarrow 2 \mathrm{CO}_{2}+2 \mathrm{~N}_{2}+3 \mathrm{H}_{2} \mathrm{O}$ \\
$\left.\mathrm{CO}_{(\mathrm{NH}}\right)_{2}$ & $2 \mathrm{CO}(\mathrm{NH})_{2}+4 \mathrm{NO}^{2}+\mathrm{O}_{2} \rightarrow 2 \mathrm{CO}_{2}+4 \mathrm{~N}_{2}+2 \mathrm{H}_{2} \mathrm{O}$ \\
$\mathrm{C}_{3} \mathrm{H}_{8}$ & $\mathrm{C}_{3} \mathrm{H}_{8}+2 \mathrm{NO}+4 \mathrm{O}_{2} \rightarrow 3 \mathrm{CO}_{2}+\mathrm{N}_{2}+4 \mathrm{H}_{2} \mathrm{O}$ \\
\hline
\end{tabular}

The basic principle of SCR denitrification process is shown in Fig. 1. This process is mainly composed of the following steps:

- Flue gas components, like $\mathrm{NO}, \mathrm{NH}_{3}, \mathrm{O}_{2}$, etc. spread into the surface of the catalyst;

-These components are adsorbed on the active sites of the catalytic surface;

-These components, like $\mathrm{NO}, \mathrm{NH}_{3}, \mathrm{O}_{2}$, etc. which are absorbed on the active sites, reacted to $\mathrm{N}_{2}$ and $\mathrm{H}_{2} \mathrm{O}$ :

-These $\mathrm{N}_{2}$ and $\mathrm{H}_{2} \mathrm{O}$ strip down from the catalytic surface;

-These $\mathrm{N}_{2}$ and $\mathrm{H}_{2} \mathrm{O}$, striped from the catalytic surface, flow out with the mainstream gas.

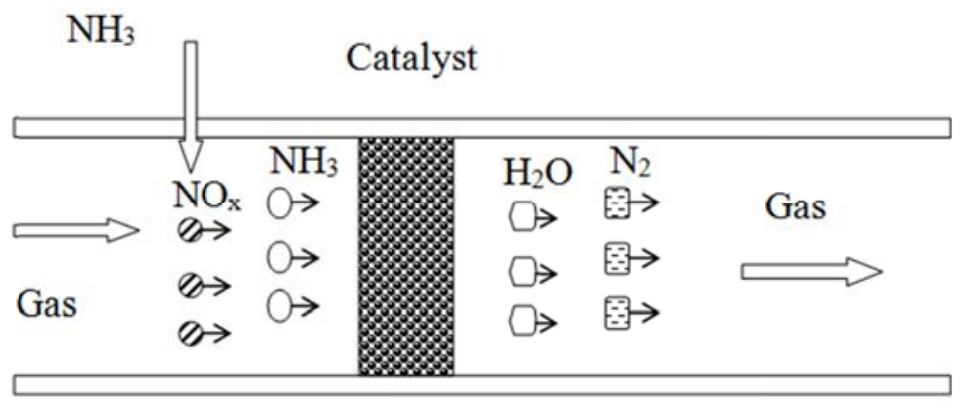

Fig. 1 Reaction process of SCR catalyst

\section{Catalyst preparation}

The development of the SCR catalyst is the core content of SCR denitrification technology, it is related to the denitrification efficiency and operating costs of SCR denitrification technology. In this paper, Mn-Ce/AC catalyst was prepared by impregnation method [11].

- First activated carbon was crushed by the high-speed grinder, and suitable size granules were screened by electric vibration sieve machine. The appropriate activated carbon particles to this experiment were obtained.

- Then these activated carbon particles were put into an appropriate amount of concentrated nitric acid, and the ambient temperature remained stable in this period. 
- Suitable $\mathrm{Ce}\left(\mathrm{NO}_{3}\right)_{3} \cdot 6 \mathrm{H}_{2} \mathrm{O}$ was dissolved in an amount of deionized water, and mixed with an appropriate amount of $\mathrm{Mn}\left(\mathrm{NO}_{3}\right)_{2}$ solution. Added those activated carbon particles had been acidulated into the liquor, kept the solution stirring on automatic mixer until one hour later.

- Activated carbon particles were dried by a muffle furnace when the stirring finished. Subsequently, these particles were roasted in $\mathrm{N}_{2}$ atmosphere with high temperature in a certain period of time. Finally, the activated carbon catalyst loading manganese and cerium can be obtained.

\section{Denitrification experiment in different types of reactors}

During the experiment, the actual flue gas which emissioned from power plants was replaced by simulated flue gas was composed of $\mathrm{NO}, \mathrm{O}_{2}, \mathrm{~N}_{2}$. The flow of each gas was regulated by the mass flow control device. The simulated flue gas was introduced into the mixing apparatus to mixing uniformly, and flowed into the low temperature SCR denitrification reactor. The flow chart of experiment system by different forms was shown in Fig. 2.

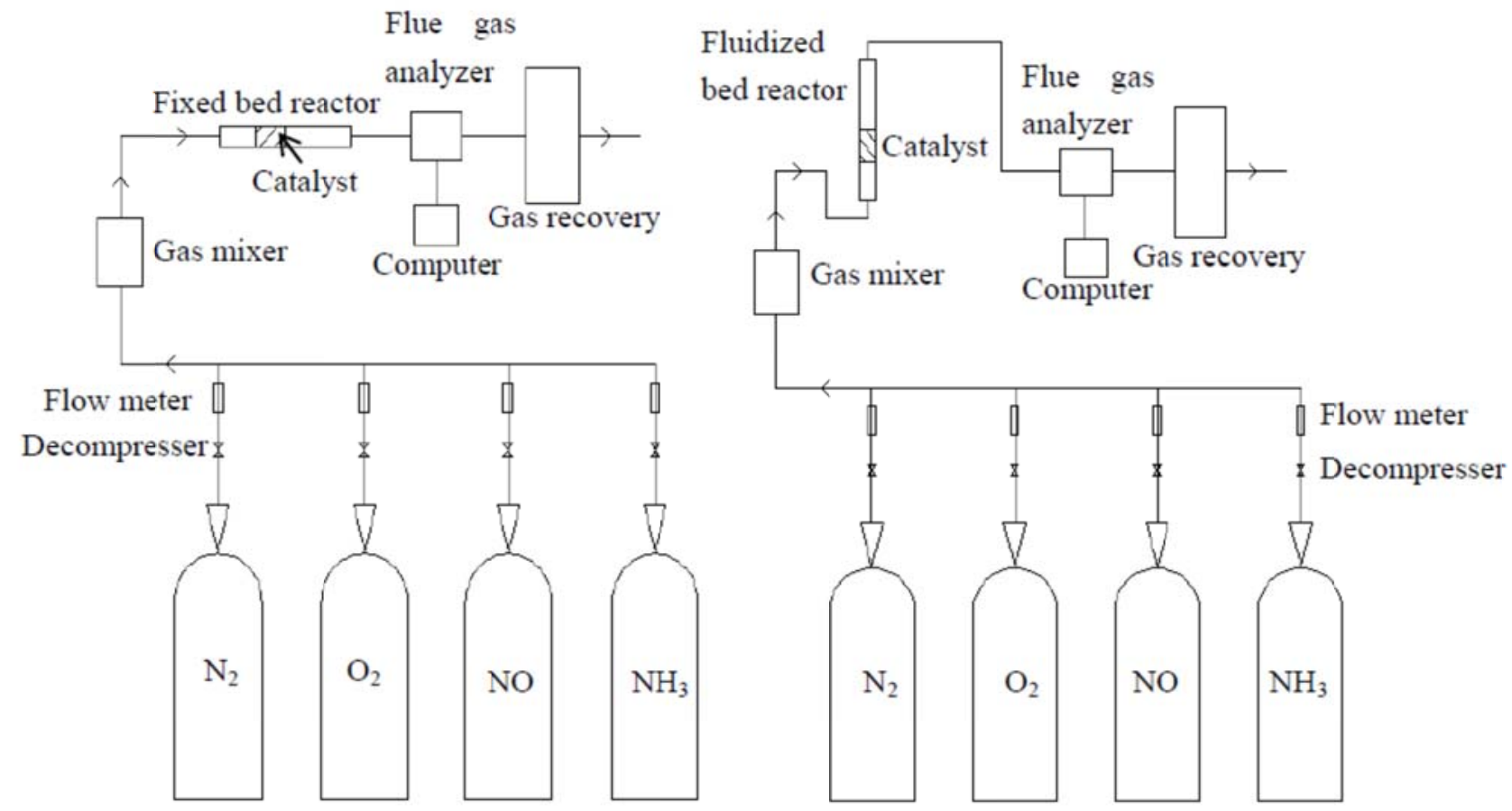

(a) Fixed bed reactor

(b) Fluidized bed reactor

Fig. 2 Flow chart of experimental system

The temperature of flue gas within denitrification reactor was controled at $180^{\circ} \mathrm{C}$, the space velocity was adjusted to $100000^{-1}$, an ideal fluidized state of the catalyst particles could be achieved in fluidized bed reactor. And the removal rate of $\mathrm{NO}$ in this experiment was defined as:

$$
\eta=\frac{\mathrm{NO}_{\text {in }}-\mathrm{NO}_{\text {out }}}{\mathrm{NO}_{\text {in }}} \times 100 \%
$$

\section{Results and discussions}

According to the experimental, the NO removal of fixed bed reactor was only $9.5 \%$, while it reached $80.3 \%$ of fluidized bed reactor at $180^{\circ} \mathrm{C}$, space velocity $100000^{-1}$. It can be seen that the NO removal of fluidized bed reactor is better than which of fixed bed reactor under low temperature high space velocity experimental condition. 
The reason for this situation is that the catalyst in fluidized bed reactor has more contact areas with reactant gas than which in fixed bed reactor, therefore, the NO removal of fluidized bed reactor much larger than which of fixed bed reactor. The NO removal of the two different reactors was shown in Fig. 3.

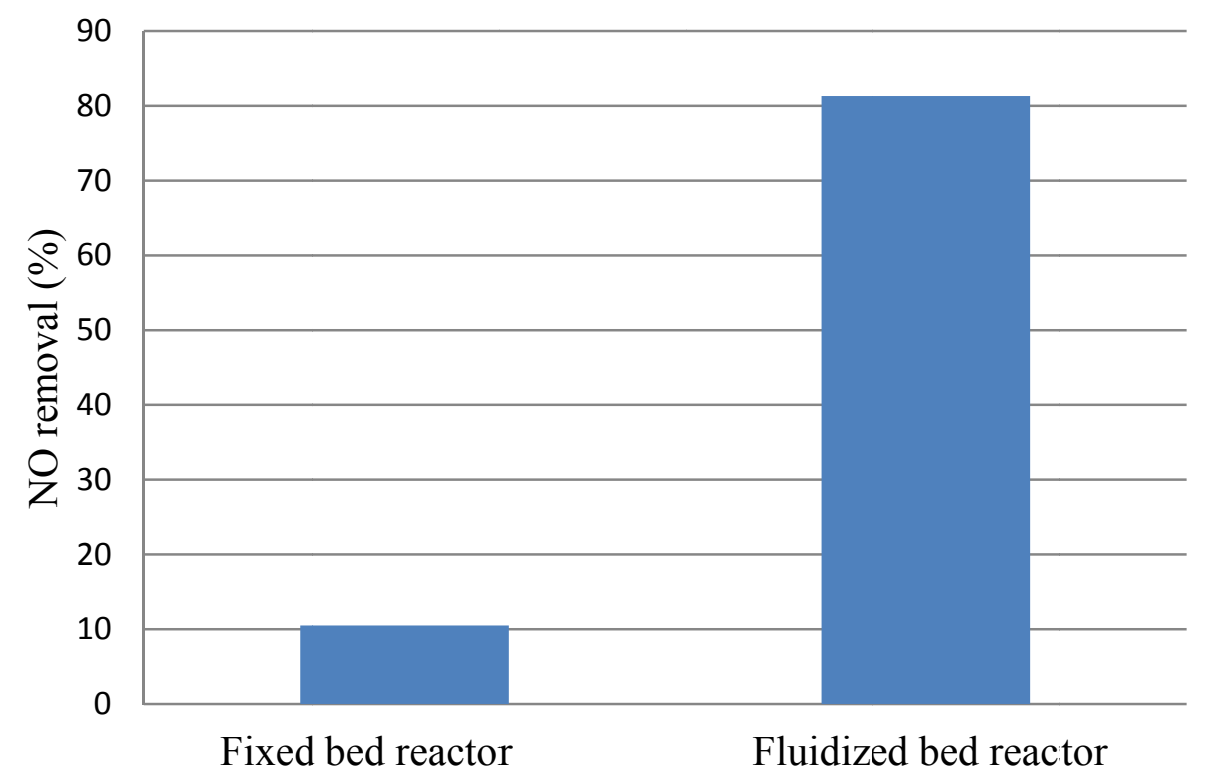

Fig. 3 The NO removal of fixed bed reactor and fluidized bed reactor

\section{Summary}

Through the denitrification experiment at low temperature high space velocity condition in this paper, the NO removal advantage of fluidized bed reactor is obvious. The NO removal rate of fluidized bed reactor is nearly eight times of fixed bed reactor. This research supply reference to development fluidized bed reactor, and offer the direction for future SCR research.

\section{Acknowledgements}

This work was financially supported by the National Natural Science Foundation of China (Grant No.51276055) and the Hebei Applied Basic Research Program of China (Grant No. 13964503D).

\section{References}

[1] Y.P. Bai, X.P. Sun: Inner Mongolia Science Technology\& Economy, Vol. 7(2009), p. 28-30

[2] X.Q. Wu: Science\& Technology Industry of China, Vol. 8(2009), p. 13-16

[3] X.Y. Zhang, X.T. Wang, and Y.F. Jiao: Power system engineering, Vol. 6(2013), p. 27

[4] P.R. Ettireddy, N. Ettireddy, and S. Mamedov: Applied Catalysis, Vol. 76(2007), p. 123-134

[5] G. Marbán, R. Antuña, A.B. Fuertes: Applied Catalysis B: Environmental, Vol. 41(2003), p. 323-338

[6] J.P. Wang, Z. Yan, L.L. Liu: Applied Surface Science, Vol. 313(2014), p. 660-669

[7] H. Zhou, G. Flamant, D. Gauthier: Chemical engineering science, Vol. 59(2004), p. 4193 - 4203 
[8] T.Y. Yang, A.R. Wang, S.J. Zhang, and X.P. Zhang: Computers and Applied Chemistry, Vol. 22(2005), p. 206-210

[9] T. Zhou, S.G. Liu, M.Z. Tang: Journal of the Chinese Ceramic Society, Vol. 2(2009), p. 317-324

[10] X. Man, W.H. Gao: Guangzhou Chemical Industry, Vol. 6(2008), p. 22-24

[11] K.H. Wang, L. Zhu, Y.F. Hu, and Y.L. Jiang: Electric power, Vol. 1(2014), p. 138-145 